\title{
Organic fertilization of Christmas tree (Abies balsamea (L.) Mill.) plantations with poultry manure in northwestern New Brunswick, Canada
}

\author{
by Manuel Lamontagne ${ }^{1}$, Hector Guy Adégbidi ${ }^{* *}$ and Abbé Jonas Assamoi²
}

\begin{abstract}
At the instigation of local growers, an experiment was conducted on balsam fir (Abies balsamea (L.) Mill.) Christmas tree plantations in northwestern New Brunswick, Canada. The objective was to compare poultry manure as an organic fertilizer to the commonly used commercial mineral fertilizer, and establish the rate and frequency of manure application. Six fertilization treatments were applied in a randomized block design monitored during five years: one control $(0 \mathrm{~g} \mathrm{~N})$, one mineral fertilizer treatment (20 g N tree-1 year $^{-1}$ as 20-10-10 (NPK)) and four poultry manure applications ((4-1-2 NPK) $20 \mathrm{~g} \mathrm{~N} \mathrm{tree}^{-1}$ year $^{-1}, 40 \mathrm{~g} \mathrm{~N}$ tree $^{-1}$ year $^{-1}, 40 \mathrm{~g} \mathrm{~N}$ tree $^{-1}$ every two years and $80 \mathrm{~g} \mathrm{~N}$ tree ${ }^{-1} / 2$ yrs). Photosynthesis, soil respiration and specific leaf area were slightly increased by the manure treatments. Height and diameter relative growth rates were similar among fertilization treatments. Manure treated trees had nutritional status similar or better than mineral fertilizer treated trees. Manure treatments had the highest percentages of dark green foliage trees appreciated by buyers. Poultry manure was as efficient as the mineral fertilizer. Considering fertilizers and operations costs, the application of poultry manure at the rate of $40 \mathrm{~g} \mathrm{~N}$ tree ${ }^{-1} / 2$ yrs seemed the one to be recommended to growers.
\end{abstract}

Key words: Christmas tree plantation, Abies balsamea, fertilization, poultry manure, nutrients, growth rate, photosynthesis rate, soil respiration, specific leaf area, foliage color

\section{RÉSUMÉ}

À la demande des producteurs locaux, on a effectué une expérience sur des plantations de sapins baumiers (Abies balsamea (L.) Mill.) pour la production d'arbres-de-Noël dans le nord-ouest du Nouveau-Brunswick, au Canada. L'objectif était de comparer le fumier de volaille comme engrais organique à l'engrais minéral commercial utilisé couramment, et d'établir le taux et la fréquence appropriés pour l'épandage du fumier. On a donc appliqué six traitements de fertilisation disposés en blocs aléatoires pour ensuite y effectuer des suivis pendant cinq ans. Ces traitements comprenaient un témoin $(0 \mathrm{~g} \mathrm{~N})$, un traitement avec des engrais minéraux ( $20 \mathrm{~g} \mathrm{~N}$ arbre $^{-1} \mathrm{an}^{-1}$ de 20-10-10 (NPK)) et quatre épandages de fumier de volaille ((4-1-2 NPK) $20 \mathrm{~g}$ de $\mathrm{N}$ arbre $\mathrm{an}^{-1}, 40 \mathrm{~g}$ de $\mathrm{N}^{-1} \mathrm{arre}^{-1} \mathrm{an}^{-1}, 40 \mathrm{~g}$ de $\mathrm{N}$ arbre-1 aux deux ans et $80 \mathrm{~g}$ de $\mathrm{N}$ arbre ${ }^{-1} / 2$ ans). Les traitements avec du fumier de volaille ont tous permis d'accroître légèrement la photosynthèse, la respiration du sol et la surface foliaire spécifique. Les taux de croissance relatifs en hauteur et en diamètre étaient similaires entre les traitements de fertilisation. L'état nutritionnel des arbres traités avec du fumier était semblable sinon meilleur que celui des arbres traités à l'engrais minéral. Les traitements au fumier présentaient les pourcentages les plus élevés d'arbres avec un feuillage vert foncé, attribut prisé par les acheteurs. Le fumier de volaille s'est avéré aussi efficace que l'engrais minéral. Compte tenu du coût des engrais et des coûts d'exploitation, il semble que l'épandage de fumier de volaille à raison de $40 \mathrm{~g} \mathrm{~N}$ arbre ${ }^{-1} / 2$ ans soit le traitement tout indiqué pour les producteurs.

Mots-clés : Plantations d'arbres-de -Noël, Abies balsamea, fertilisation, fumier de volaille, nutriments, taux de croissance, taux de photosynthèse, respiration du sol, surface foliaire spécifique, coloration du feuillage

\footnotetext{
${ }^{1}$ École de foresterie, Université de Moncton Campus d'Edmundston, 165, boul. Hébert, Edmundston, N.-B. E3V 2S8, Canada; ${ }^{\star C}$ Corresponding author: hector.guy.adegbidi@umoncton.ca

${ }^{2}$ Ministère de l'Environnement et du Développement Durable, Secrétariat Permanent REDD+, Côte d'Ivoire
} 


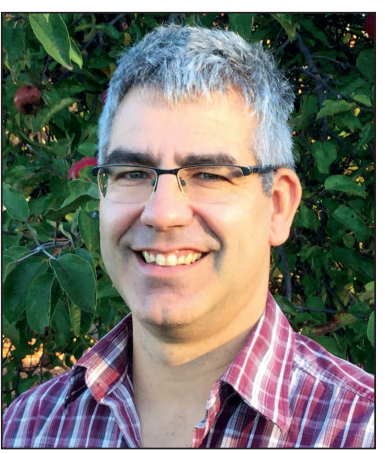

Manuel Lamontagne

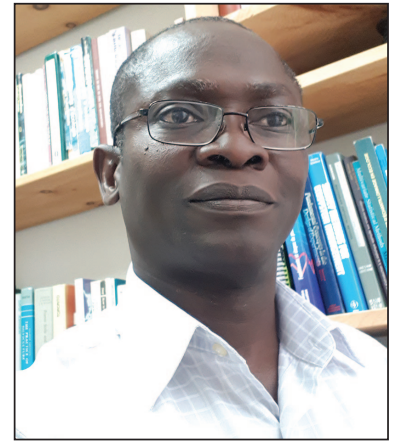

Hector Guy Adégbidi

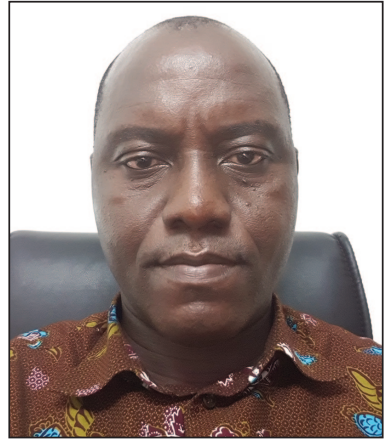

Abbé Jonas Assamoi

maximizes light capture and $\mathrm{CO}_{2}$ uptake (Field et al. 1983), thereby minimizing the cost of biomass production. According to Cornelissen (1999) and Westoby (1998), SLA is the most commonly used parameter for assessing the capacity of leaves in capturing light. Various studies (Brix 1983; Smolander and Oker-Blom 1989; Mitchell and Hinckley 1993; Sheriff 1996) have observed that photosyn-

\section{Introduction}

In New Brunswick, as well as in all of eastern Canada, Christmas tree production is an important economic activity. Indeed, since its establishment in Canada around 1945, it has become a significant source generating export revenues of approximately \$7.9 million in New Brunswick (Statistics Canada 2016). Balsam fir (Abies balsamea (L.) Mill.) is the main species grown as Christmas trees in eastern Canada (Guertin et al. 2018). The use of fertilizers has resulted in a significant decrease of the rotation length (time from planting to harvesting) in those plantations (Bondi et al. 2000; Hinesley et al. 2000; Koelling 2002). However, fertilization costs have also recently increased with the rise in oil prices. As the cost of mineral fertilizers is becoming a major burden for growers, the Christmas tree production business starts to lose some of its attractiveness. Meanwhile, in northwestern New Brunswick there has been a flourishing poultry industry generating tons of manure that need to be disposed of. It has been proposed to recycle this poultry manure as a nutrient source for Christmas tree plantations. Poultry manure contains nutrients needed for plant growth and various studies (Wilhoit et al. 1999; Richardson et al. 2004; Tejada et al. 2006) have shown its effectiveness in the growth of conifers in plantations, in addition to improving the physico-chemical and biological properties of the soil. During 2004 in New Brunswick, poultry manure conditioned as organic fertilizer retailed at $\$ 80$ per metric ton, compared to $\$ 400$ per metric ton for mineral chemical fertilizer. As a result, Christmas tree producers requested that organic fertilization with poultry manure be investigated as an alternative to the chemical fertilizers they commonly use. Bruns (1973) noted that fertilization affects the quality of a Christmas tree in many respects. Nitrogen treatments alone or in combination with phosphorus and potassium produce denser, darker-green foliage with larger needles. Fertilization is beneficial to trees as it increases the amount of nitrogen that is released and available in the soil (Miller 1981; Meason et al. 2004). Also, various studies (Vose and Allen 1988; Teskey et al. 1994; Albaugh et al. 1998) have shown that fertilization increases leaf area in pines, thereby improving productivity through high carbon fixation. Leaf mass and leaf area in the maritime pine (Pinus pinaster Aiton) and other conifers increased with the application of fertilizer (Brix 1983; Sheriff 1996) resulting in a higher specific leaf area (SLA). The SLA (leaf area per unit of dry biomass) is recognized as one of the most important functional attributes of plants (Lambers et al. 1998). A high SLA

thetic rate and efficiency are largely affected by soil fertility. Organic amendments improve physico-chemical and biological properties of the soil by increasing soil organic matter content and the availability of nutrients for crops (Brady and Weil 2002). Various studies (Swift et al. 1979; Diaz-Raviña et al. 1993; Killham 1994; Bauhus and Khanna 1999) have demonstrated the importance of organic matter for plant mineral nutrition through mineralization/immobilization by microbial activity as a reservoir where nutrients are formed in the soil and slowly released to meet plant needs, especially during periods of high biological activity (Chabalier et al. 2006). When used in plantations, poultry manure increased loblolly pine (Pinus taeda L.) volume growth (Richardson et al. 2004), stem diameter (Wilhoit et al. 1999), and microbial biomass of soils (Tejada et al. 2006). Nutritional status of plants influences their crop quality and yield. Usually nutrient element concentrations in tissues are good indicators of the nutritional status and when an imbalance occurs, visual symptoms appear and leaf coloration changes (Pritchett and Fisher 1987). Foliar analysis is the most commonly used method to assess the nutritional status of Christmas trees. In addition to indicating the critical levels of nutrient concentrations (Van den Driessche 1974; Paarlahti et al. 1971), foliar analysis provides justification for possible changes in fertilization programs. Various approaches based on results of foliar analyses - including critical levels, technical ratios, integrated diagnostic and recommendation system (DRIS), and vector analysis - are used to assess the nutritional status of plants (Van den Driessche 1974; Timmer and Stone 1978; Pritchett and Fisher 1987; Imo and Timmer 1997). Landis et al. (1989) and Parent et al. (2005) developed standards for optimal foliar nutrient concentrations for balsam fir and Fraser fir (Abies fraseri (Pursh) Poir) grown as Christmas trees as well as for nursery pines and spruces. Havlin et al. (1999) have mentioned that critical concentrations are reached when tree growth decreases by $10 \%$, even in the absence of visual symptoms. Moore et al. (1995) have observed that poultry litter is one of the best organic fertilizers available and found that in the United States, almost $90 \%$ of litter produced by the poultry industry was used on farmland because of its low cost compared to commercial fertilizers. Kingery et al. (1993) and Sommerfeldt et al. (1988) have noted an improvement in the physicochemical properties of soils amended with poultry manure compared to untreated soils. Similarly, Edwards and Daniels (1992) noted that poultry waste would increase crop production through its ability 
to provide nutrients and increase soil quality. Despite such evidence, in northwestern New Brunswick, Christmas tree growers are still not making use of the manure generated by the local poultry industry due to a lack of information on the rates of manure application.

The aim of this study was to assess the validity of organic fertilization with poultry manure as an alternative to the mineral fertilization regime used by local Christmas tree growers of northwestern New Brunswick. Nitrogen was used as a reference element. The commonly used mineral fertilization formula, which provides $20 \mathrm{~g} \mathrm{~N}$ tree $^{-1}$ year $^{-1}$, was compared with four organic fertilization treatments and a control treatment. Specifically, the effects of the various treatments on (i) height and diameter growth, (ii) foliage coloration, (iii) maximum photosynthetic rate (Amax), (iv) soil respiration, (v) specific leaf area, and (vi) foliage nutrient concentrations were investigated.

\section{Materials and methods}

Two balsam fir plantations owned by different Christmas tree growers in northwestern New Brunswick were used as study sites. The first plantation is located in Saint-Quentin (47 $30^{\prime} 35^{\prime \prime}$ North, 67 $23^{\prime} 18^{\prime \prime}$ West) at an altitude of $300 \mathrm{~m}$ a.s.l. in the centre of a plateau in the Appalachian Mountains. The land is flat and covered mostly with forests and farmland. The soil is of the McGee series with a loamy to silty texture and a pH ranging from 5.5 to 6.5 (Langmaid et al. 1976). Average temperatures are $-12^{\circ} \mathrm{C}$ and $17^{\circ} \mathrm{C}$, respectively, for January and August (Van Groenewoud 1983). The average annual precipitation is about $991 \mathrm{~mm}$. The second plantation is located in Connors ( $47^{\circ} 13^{\prime} 0^{\prime \prime}$ North; 68 $49^{\prime} 59^{\prime \prime}$ West), approximately $50 \mathrm{~km}$ west of Edmundston at an elevation of $182 \mathrm{~m}$. The land is hilly and the territory is mostly covered with forests and farmland. The soil is of the Glassville series with a loamy to silty texture and a $\mathrm{pH}$ ranging from 5.0 to 5.5 (Langmaid et al. 1980). The average annual precipitation is about $976 \mathrm{~mm}$. Average temperatures are $-7.4^{\circ} \mathrm{C}$ and $23^{\circ} \mathrm{C}$, respectively in January and August (Van Groenewoud 1983). The experiment was a complete randomized block design of six fertilization treatments monitored over a 5-year period. A total of four blocks were used, two at each of the two sites. Experimental units were rows of trees. Each block was made up of thirteen parallel rows of trees, comprising six rows for the six fertilization treatments, one row as a buffer zone between two adjacent treatment rows and two external rows delineating the block. The spacing between and within rows was approximately $2 \mathrm{~m}(6-7 \mathrm{ft})$ for an average density of 2500 trees per hectare. The design comprised a total of 575 trees. The chemical fertilizer commonly used by local growers, called McCain fertilizer, is a 20-10-10 (NPK) formulated ammonium nitrate applied at $115 \mathrm{~g} \mathrm{tree}^{-1}$ year $^{-1}$, equivalent to $23 \mathrm{~g}$ of total $\mathrm{N}$ delivered to each tree. The manure is a dehydrated and non-composted poultry manure obtained in bulk by Christmas tree growers from WestCo, a subsidiary of Envirem Technologies Inc. Manure (4.12\% nitrogen; Table 1) treatments, applied at the base of the trees, were chosen to delivered approximately once or twice of the $\mathrm{N}$ rate above. The six treatments were (1) control, $0 \mathrm{~g} \mathrm{~N}$ tree $^{-1}$ year $^{-1}$; (2) 115 g of mineral fertilizer 20-10-10 (NPK) tree tear $^{-1}$; (3) 0.5 $\mathrm{kg}$ of poultry manure tree ${ }^{-1}$ year $^{-1}$; (4) $1 \mathrm{~kg}$ of poultry manure tree $^{-1}$ year $^{-1}$; (5) $1 \mathrm{~kg}$ of poultry manure tree $/ 2 \mathrm{yrs}$; (6) $2 \mathrm{~kg}$

Table 1. Concentrations of mineral elements in the poultry manure dry powder used as organic fertilizer in the 2004-2008 experiment of poultry manure fertilization of Christmas tree plantations in northwestern New Brunswick

Element

$\begin{array}{lc} & (\%) \\ \text { Nitrogen (N) } & 4.12 \\ \text { Phosphorus (P) } & 1.18 \\ \text { Potassium (K) } & 2.07 \\ \text { Calcium (Ca) } & 3.00 \\ \text { Magnesium (Mg) } & 0.41 \\ \text { Iron (Fe) } & 0.5 \\ & \\ \text { Manganese (Mn) } & (\mathbf{p p m}) \\ \text { Zinc (Zn) } & 328 \\ \text { Copper (Cu) } & 294 \\ \text { Boron (B) } & 66 \\ \end{array}$

Source: Envirem Technologies Inc.

of poultry manure tree $e^{-1} / 2$ yrs. The investigation began when the trees were two-years-old and thus had all received, up to that point, the common mineral fertilization regime. All trees were from wild seedlings collected from the local forested land. Every year during the course of this study from 2004 to 2008, fertilization treatments were applied in June.

For height and diameter growth measurements, each tree in each treatment row was identified and measured for height with a 5-m expandable metric ruler and diameter at stump level using a Vernier caliper. Annual relative growth rates (RGR) were computed using the formula below (Margolis and Brand 1990):

$$
R G R\left(y r^{-1}\right)=\frac{\ln \left(H_{2}\right)-\ln \left(H_{1}\right)}{t_{2}-t_{1}}
$$

where $\mathrm{H}_{1}$ and $\mathrm{H}_{2}$ correspond to the height or diameter of the stem in $\mathrm{mm}$ at the beginning and at the end of the sampling period, and $t_{1}$ and $t_{2}$ the sampling year.

Foliage color recordings were performed on the same day as height and diameter measurements from 2004 to 2008, and included all the 575 trees in the experiment. Foliage color was taken on current year needles in the field using SICO paint color samples. Field colors according to the SICO samples were later combined and matched with colors of the Munsell color chart (Munsell Color 1977) based on the strongest resemblance of the colors.

Measurements of the maximum photosynthetic rate (Amax) of annual shoots were taken in the field from May to August 2006. One tree was randomly selected per experimental unit and measured. A LI-6400 apparatus (Li-cor, Nebraska, USA) set at 400 ppm $\mathrm{CO}_{2}$ concentration and 1000 $\mu \mathrm{mol} \mathrm{m} \mathrm{m}^{-2} \mathrm{~s}^{-1}$ luminous intensity was used, with artificial lighting (halogen lamp, 1000 watts) to ensure that the foliage was saturated. Subsequently, the area of needles exposed to light was measured in the laboratory using Windseedle software (Regent Instruments Inc., Quebec). These needles were then oven-dried at $65^{\circ} \mathrm{C}$ for 48 hours and weighed (Mettler AE 260 Delta Range) to calculate the specific leaf area (SLA), expressed in square centimeter per gram $\left(\mathrm{cm}^{2} \mathrm{~g}^{-1}\right)$. 
Soil respiration was measured at the same time of photosynthetic measurements using the LI-6400 (Li-cor, Nebraska, USA) equipped with a soil $\mathrm{CO}_{2}$ flow chamber (LI-6400-09). This flow chamber was installed on a collar sunk into the soil two to three hours before measurements at the base of the trees, and the $\mathrm{CO}_{2}$ mainly produced by root respiration and microbial activity was measured (350 ppm target, delta 10 ppm, three cycles). A soil temperature probe was dug into the soil at an appropriate depth (usually 5 to $10 \mathrm{~cm}$ ) near the soil respiration chamber.

Current season needle samples were collected every year in September-October, at a point when needle nutrient levels were relatively stable and best reflected the nutritional state of the plant. Approximately 75 to $100 \mathrm{~g}$ of needle were collected from each of five randomly selected trees in each experimental unit and thoroughly mixed to make a composite sample. Samples were then dried and analyzed for mineral elements. Observed concentrations were assessed by comparison to the lowest thresholds of adequate concentration ranges deemed to represent critical levels (Table 2). An additional 250 needles were selected from each experimental unit, dried and weighed to estimate specific needle mass, i.e., average mass per needle.

A repeated-measures analysis of variance (RM-ANOVA) was performed using SPSS data processing software (version 23.0, SPSS Inc., Chicago, IL) to assess the effects of time and fertilization treatments on nutrients concentrations and ratios, as well as height and diameter relative growth rates (RGR) and foliage color observations. Whenever fertilization treatments were significant, the Tukey multiple comparison test was used to separate means. A one-way ANOVA was performed on the seasonal average of maximum photosynthetic rate (Amax), specific leaf area (SLA) and soil respiration. All statistical tests were assessed using a 5\% significance level.

Table 2. Adequate concentration ranges and ratios for macroelements and micro-elements in current season needle of firs (Abies), spruce (Picea) and pines (Pinus)

\begin{tabular}{|c|c|c|c|c|}
\hline \multirow[b]{2}{*}{ Element } & \multirow{2}{*}{$\begin{array}{c}\text { Chemical } \\
\text { symbol }\end{array}$} & \multicolumn{2}{|c|}{ Adequate concentrations } & \multirow{2}{*}{$\begin{array}{c}\text { Ratio } \\
\text { to } \\
\text { Nitro } \\
\text { gen }^{b}\end{array}$} \\
\hline & & Abies $^{\mathrm{a}}$ & Picea \& Pinus ${ }^{\mathrm{b}}$ & \\
\hline \multicolumn{2}{|l|}{ Macro-element } & (\%) & $(\%)$ & \\
\hline Nitrogen & $\mathrm{N}$ & $1.78-2.60$ & $1.40-2.20$ & 1.00 \\
\hline Phosphorus & $\mathrm{P}$ & $0.18-0.27$ & $0.20-0.40$ & 0.20 \\
\hline Potassium & K & $0.56-0.91$ & $0.40-1.50$ & 0.55 \\
\hline Calcium & $\mathrm{Ca}$ & $0.57-1.18$ & $0.20-0.40$ & 0.06 \\
\hline Magnesium & $\mathrm{Mg}$ & $0.06-0.14$ & $0.10-0.30$ & 0.05 \\
\hline Sulfur & $\mathrm{S}$ & - & $0.20-0.30$ & 0.09 \\
\hline \multicolumn{2}{|l|}{ Micro-element } & & $(\mathrm{ppm})$ & \\
\hline Iron & $\mathrm{Fe}$ & - & $60-200$ & 0.007 \\
\hline Manganese & $\mathrm{Mn}$ & - & $100-250$ & 0.004 \\
\hline Zinc & $\mathrm{Zn}$ & - & $30-150$ & 0.0003 \\
\hline Copper & $\mathrm{Cu}$ & - & $4-20$ & 0.0003 \\
\hline Molybdenum & Mo & - & $0.25-5.00$ & 0.00007 \\
\hline Boron & $\mathrm{B}$ & - & $20-100$ & 0.002 \\
\hline Chloride & $\mathrm{Cl}$ & - & $2-20$ & 0.0003 \\
\hline
\end{tabular}

\footnotetext{
aAdapted from Parent et al. (2005)
}

bAdapted from Landis et al. (1989)

\section{Results}

\section{Height and diameter relative growth rates}

The average height relative growth rate (HRGR) during the five-year period of the study ranged from $0.21 \mathrm{yr}^{-1}\left(1 \mathrm{~kg} \mathrm{yr}^{-1}\right)$ to $0.24 \mathrm{yr}^{-1}$ (1 kg/2 yrs) (Table 3). This implies that for trees receiving $1 \mathrm{~kg} / 2$ yrs, their height annually increased by $27 \%$ during the period of the study. Height RGR exhibited a significant annual trend, decreasing from the first to the last year of the study $(p=0.000)$, whereas there was no significant fertilization effect $(\mathrm{p}=0.391$; Table 3$)$ and fertilization by year interaction (Table 3 ).

The average diameter relative growth rate (DRGR) during the five-year period ranged from 0.29 (Control) to $0.31 \mathrm{yr}^{-1}$ (1 kg/2 yrs) (Table 3). This implies that for trees receiving $1 \mathrm{~kg} / 2 \mathrm{yrs}$, their basal diameter annually increased by $36 \%$ during the period of the study. Diameter RGR also decreased significantly with time $(p=0.000)$. However, the effects of fertilization treatments $(\mathrm{p}=0.922$; Table 3 ) and fertilization by year interaction were not significant (Table 3 ).

\section{Foliage color}

Based on the Munsell color codes, four different colors were observed in Christmas trees during the study period. These colors ranged from light green to very dark green. The predominant one was dark green (7.5 GY 4/2), with an average observed frequency ranging from $84 \%$ (Control) to $96 \%$ (1 kg $\mathrm{yr}^{-1}$ ) (Fig. 1). The light green color (2.5 GY 5/4) was the second in average frequencies, ranging from $3 \%(2 \mathrm{~kg} / 2 \mathrm{yrs})$ to 9\% (Control) (Fig. 1). The two other colors were less present with overall averages of 3.8 and $0.7 \%$ for green ( 5 GY 5/4) and very dark green ( $5 \mathrm{G} \mathrm{3/2}$ ), respectively. While the percentages of green and very dark green were not affected by fertilization treatments, those of the light green $(p=0.019)$ and dark green $(\mathrm{p}=0.023)$ differed significantly among fertilization treatments (Fig. 1). The control group had the highest percentage of trees with light green foliage (9\%) and the lowest with dark green foliage ( $84 \%)$, whereas poultry manure treat-

Table 3. Means and standard errors (SE) of fertilization treatments and repeated-measures ANOVA probability values ( $p$ ) for height (HRGR) and diameter (DRGR) relative growth rates in the 2004-2008 experiment of poultry manure fertilization of Christmas tree plantations in northwestern New Brunswick

\begin{tabular}{lcc}
\hline $\begin{array}{l}\text { Fertilization } \\
\text { Treatment }\end{array}$ & $\begin{array}{c}\text { HRGR } \\
(\mathbf{l n}(\mathbf{r a t i o}) / \mathbf{y r})\end{array}$ & $\begin{array}{c}\text { DRGR } \\
(\mathbf{l n}(\mathbf{r a t i o}) / \mathbf{y r})\end{array}$ \\
\hline Control & 0.22 & 0.29 \\
$20-10-10$ & 0.22 & 0.29 \\
$0.5 \mathrm{~kg} / \mathrm{yr}$ & 0.23 & 0.29 \\
$1 \mathrm{~kg} / \mathrm{yr}$ & 0.21 & 0.29 \\
$1 \mathrm{~kg} / 2$ yrs & 0.24 & 0.31 \\
$2 \mathrm{~kg} / 2$ yrs & 0.24 & 0.31 \\
S.E. & 0.012 & 0.016 \\
\hline p-values & & \\
\hline Fertilization & & 0.922 \\
Year & 0.391 & 0.000 \\
Year x Fertilization & 0.000 & 0.522 \\
\hline
\end{tabular}




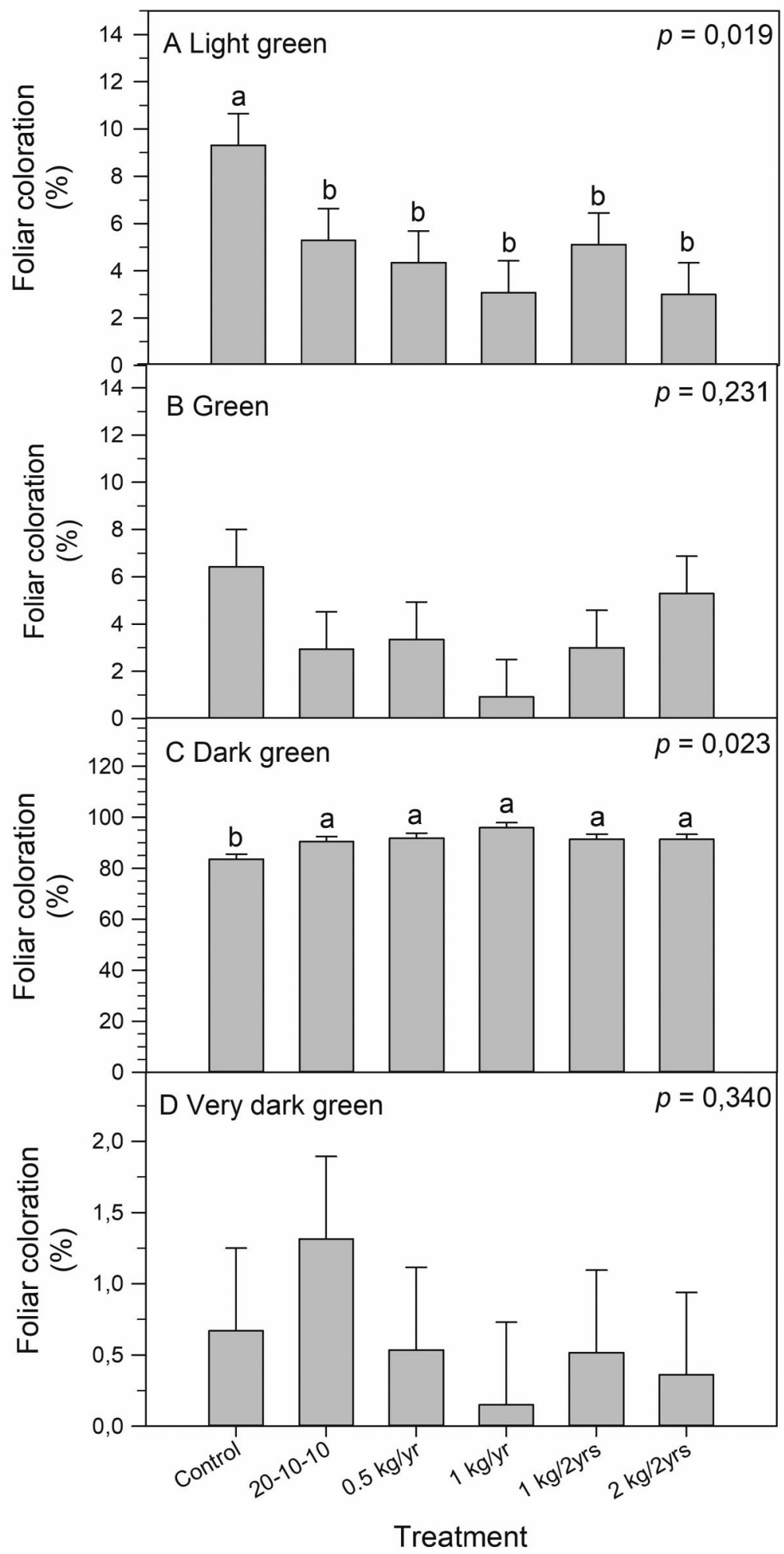

Fig. 1 Means and standard errors of fertilization treatments for foliar coloration in the 2004-2008 experiment of poultry manure fertilization of Christmas tree plantations in northwestern New Brunswick (bars with the same letter indicate no statistical difference at 0.05 significance level] 
ments had the lowest percentage of trees with light green foliage ( $3 \%$ for $2 \mathrm{~kg} / 2 \mathrm{yrs}$ ) and the highest percentage with dark green foliage (96\% for $1 \mathrm{~kg} \mathrm{yr}^{-1}$ ) (Fig. 1).

\section{Maximum photosynthetic rate (Amax)}

Maximum photosynthetic rate averaged over the growing season (May to August 2006) ranged from 6.3 to $8 \mu \mathrm{mol} \mathrm{m}{ }^{-2} \mathrm{~s}^{-1}$. Poultry manure treatments tended to have higher Amax in comparison to mineral fertilizer and control treatments. However, fertilization effect on Amax was not significant ( $p=0.134$; Fig. 2A).

\section{Soil respiration}

Soil respiration, measured as $\mathrm{CO}_{2}$ fluxes, averaged between 4.0 and $5.2 \mu \mathrm{mol} \mathrm{m}{ }^{-2} \mathrm{~s}^{-1}$ during the growing season. Poultry manure treatments tended to have higher respiration rates than mineral fertilizer and control treatments, but the overall effect of fertilization was only marginally significant ( $\mathrm{p}=0.078$; Fig. 2B).

\section{Specific leaf area (SLA)}

Specific leaf area (SLA) varied from 136 (Control) to $160 \mathrm{~cm}^{2} \mathrm{~g}^{-1}$ $\left(1 \mathrm{~kg} \mathrm{yr}^{-1}\right)$ (Fig. 2C). The effect of fertilization treatments was significant ( $\mathrm{p}=0.019$ ), with manure treatments exhibiting higher SLA than the controls. SLA also varied during the growing season, increasing to a maximum in June and decreasing afterwards. However, current year needle specific mass remained constant across all treatments, averaging $6.6 \pm 0.1$ mg per needle.

Foliage concentrations of nutrients Mean concentrations of macroelements ranged from 2.08 (Control) to $2.26 \%\left(1 \mathrm{~kg} \mathrm{yr}^{-1}\right)$ for $\mathrm{N}$; from $0.22\left(0.5 \mathrm{~kg} \mathrm{yr}^{-1}\right)$ to $0.23 \%$ (Control) for P; from 0.60 (20-10-10) to $0.65 \%$ ( $1 \mathrm{~kg} / 2 \mathrm{yrs})$ for $\mathrm{K}$; from $0.52\left(0.5 \mathrm{~kg} \mathrm{yr}^{-1}\right)$ to $0.55 \%$ (Control) for $\mathrm{Ca}$; and from $0.08\left(1 \mathrm{~kg} \mathrm{yr}^{-1}\right)$ to $0.09 \%$ (Control) for Mg (Table 4; Fig. 3). Fertilization was only significant on $\mathrm{P}(\mathrm{p}=0.041)$ and $\mathrm{Mg}(\mathrm{p}=0.037)$ concentrations (Fig. 3): for both elements, the control treatment had the highest concentrations. For all macro-nutrients, significant annual trends were observed with the highest concentrations generally observed in the earlier years, whereas the lowest concentrations were found in later years $(p=0.000$; Table 4$)$.
Calcium was consistently below the critical level of foliar concentration (cf. Table 2) for all treatments, whereas other macro-elements were above critical concentration levels (cf. Table 2).

Calcium/magnesium and phosphorus/calcium ratios showed no significant differences among fertilization treatments (Table 4), whereas the control treatment had a significantly lower N/P ratio than all other treatments (Fig. 3a). All nutrient ratios were also above critical levels (cf. Table 2).

Mean concentrations of microelements ranged from 162 


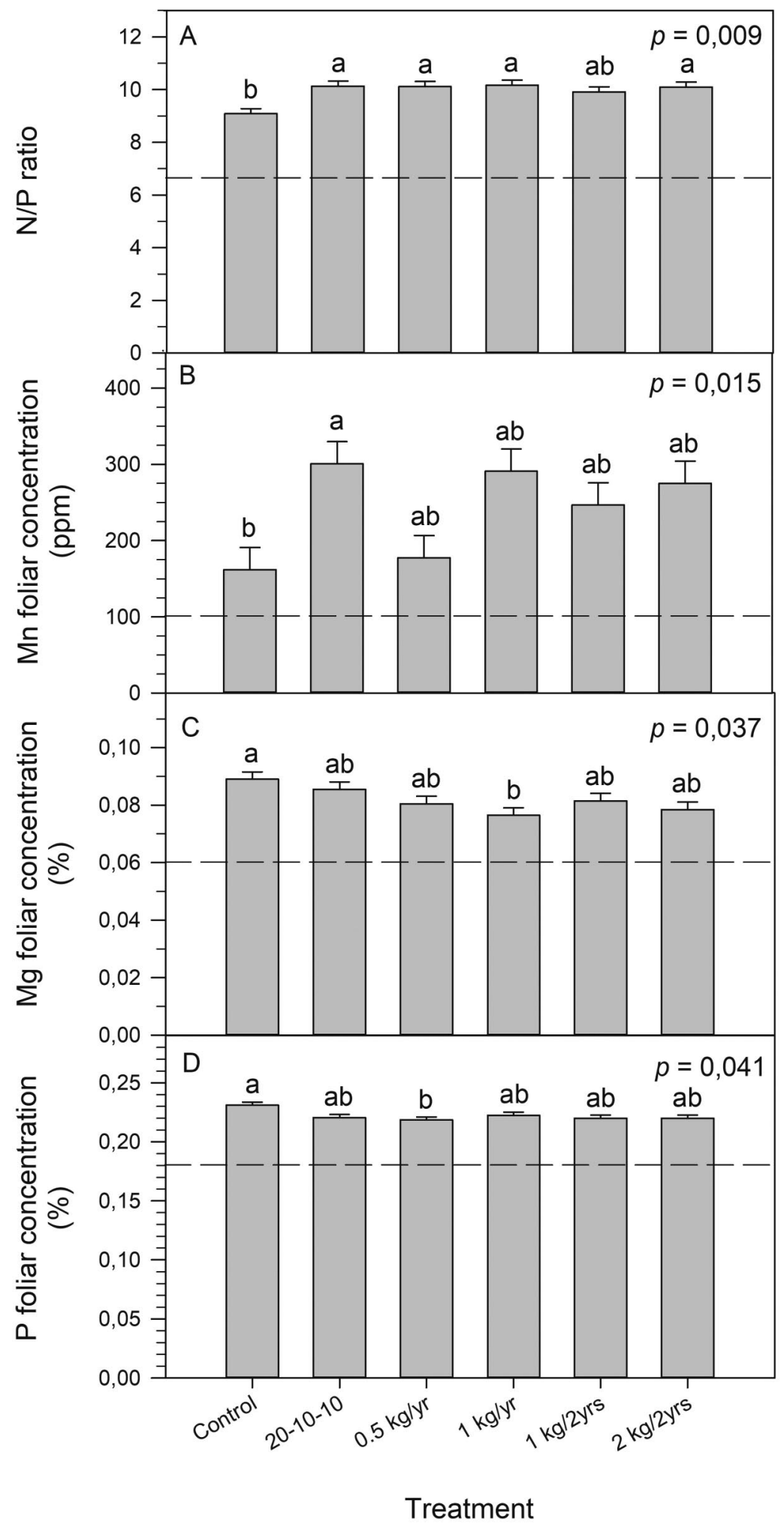

Fig. 3 Means and standard errors of fertilization treatments for phosphorus, magnesium and manganese foliar concentrations, and nitrogen/phosphorus foliar ratio in the 2004-2008 experiment of poultry manure fertilization of Christmas tree plantations in northwestern New Brunswick (bars with the same letter indicate no statistical difference at 0.05 significance level) 
Table 4. Means and standard errors (SE) of fertilization treatments and repeated-measures ANOVA contrasts probability values (p) for selected nutrient concentrations and ratios in the 2004-2008 experiment of poultry manure fertilization of Christmas tree plantations in northwestern New Brunswick

\begin{tabular}{|c|c|c|c|c|c|c|c|}
\hline $\begin{array}{l}\text { Fertilization } \\
\text { Treatment }\end{array}$ & $\begin{array}{l}\mathrm{N} \\
(\%)\end{array}$ & $\begin{array}{c}\mathrm{K} \\
(\%)\end{array}$ & $\begin{array}{l}\mathrm{Ca} \\
(\%)\end{array}$ & $\begin{array}{c}\mathrm{Fe} \\
(\mathrm{ppm})\end{array}$ & $\begin{array}{c}\mathrm{Zn} \\
(\mathrm{ppm})\end{array}$ & $\mathrm{Ca} / \mathrm{Mg}$ & $\mathrm{P} / \mathrm{Ca}$ \\
\hline Control & 2.08 & 0.63 & 0.55 & 46.80 & 80.00 & 6.43 & 0.47 \\
\hline $20-10-10$ & 2.23 & 0.60 & 0.54 & 49.45 & 78.15 & 6.29 & 0.46 \\
\hline $0.5 \mathrm{~kg} / \mathrm{yr}$ & 2.20 & 0.64 & 0.52 & 45.90 & 74.95 & 6.54 & 0.45 \\
\hline $1 \mathrm{~kg} / \mathrm{yr}$ & 2.26 & 0.62 & 0.52 & 46.35 & 76.40 & 6.89 & 0.47 \\
\hline $1 \mathrm{~kg} / 2 \mathrm{yrs}$ & 2.18 & 0.65 & 0.54 & 46.20 & 71.95 & 6.88 & 0.45 \\
\hline $2 \mathrm{~kg} / 2 \mathrm{yrs}$ & 2.21 & 0.63 & 0.54 & 48.55 & 73.70 & 6.95 & 0.48 \\
\hline S.E. & 0.041 & 0.013 & 0.025 & 1.78 & 4.40 & 0.31 & 0.02 \\
\hline \multicolumn{8}{|l|}{ p-values } \\
\hline Fertilization & 0.106 & 0.296 & 0.922 & 0.658 & 0.807 & 0.425 & 0.898 \\
\hline Year & 0.000 & 0.000 & 0.000 & 0.000 & 0.000 & 0.000 & 0.000 \\
\hline Year x Fertilization & 0.020 & 0.147 & 0.787 & 0.594 & 0.771 & 0.553 & 0.407 \\
\hline
\end{tabular}

(Control) to $301 \mathrm{ppm}$ (20-10-10) for Mn (Fig. 3b); from 46 $\left(0.5 \mathrm{~kg} \mathrm{yr}^{-1}\right)$ to $49 \mathrm{ppm}(20-10-10)$ for Fe (Table 4), and from 72 (1 kg/2 yrs) to $80 \mathrm{ppm}$ (Control) for Zn (Table 4). Fe concentrations were consistently below the critical level for all treatments. Treatment effect was only significant for $\mathrm{Mn}(\mathrm{p}=$ 0.015), with the controls having the lowest Mn concentration. The effect of year was significant, whereas that of fertilization by time interaction was not significant (Table 4).

\section{Discussion}

In this study, no effects of treatments on the average height relative growth rate (HRGR) was observed (Table 3). This may be explained by the fact that, in order to have trees that look "full and bulky" with many lateral branches, producers annually cutback the terminal shoots which are actually the ones that elongate and readily express the actual height growth resulting from fertilization. Such tree shaping operations likely caused a bias in height data, preventing the observation of treatment effect on HRGR. Presumably in this experiment, terminal shoot cutting was more severe in fertilized treatments due to the need for maintaining the aesthetics of the faster growing trees. The annual trend of HRGR decreasing from the beginning to the end of the study period is expected as, even with a higher absolute growth from one year to the next, the ratio of such growth over the increasing height could generate a lower relative growth rate from one year to the next.

Fertilization also had no statistically significant effect on ground level DRGR, although the $1 \mathrm{~kg} / 2$ yrs and $2 \mathrm{~kg} / 2 \mathrm{yrs}$ treatments seemed to result in higher DRGR (Table 3). Various studies have shown that soil incorporation of organic amendments produces increased microbial activity (Elliott and Lynch 1994; Liu and Ristaino 2003), and microbial diversity (Girvan et al. 2004), resulting in increased tree growth. Wilhoit et al. (1999) observed increases of 38 and 25\% in stem diameter growth of Pinus taeda fertilized with poultry manure and mineral fertilizer (diammonium phosphate), respectively. Richardson et al. (2004) showed that four years after application of mineral treatment and poultry manure in plantation-grown Pinus taeda, poultry manure increased tree volume by $42 \%$ and $44 \%$ in comparison to the control and mineral treatments, respectively. Unlike tree height, where diameter is not directly impacted by the annual cutback operation, one would have expected some fertilization effects. However, it is possible that the annual cutback and tree shaping has reduced SLA of manure fertilized trees, thereby preventing them to accumulate enough photosynthates to significantly increase their diameter in comparison to the non-fertilized control trees.

In this study, foliage color was similar between the poultry manure treatments and the mineral fertilizer treatment traditionally used by producers (Fig. 3). Observed foliage coloration clearly indicated that non-fertilized control trees had a higher percentage of light green color (2.5 GY 5/4) that makes them less desirable to buyers, whereas fertilized trees, mainly the poultry manure ones, had a higher percentage of dark green color (7.5 GY 4/2) that is more appealing to buyers (Fig. 1). In the controls, the percentage of dark green was much lower compared to fertilized treatments. Although significant, this decrease did not seem dramatic. Slesak and Briggs (2007) also found darker foliage color in chemically fertilized trees compared to control trees. The dark green color exhibited by a high percentage of treated trees compared to control trees is probably also an indication of better nutritional and health status of those trees. It suggests that the major mineral elements, such as nitrogen and magnesium, essential components of chlorophyll, were in adequate proportions. However, Hart et al. (2004) argued that foliar magnesium concentration does not appear to be correlated with foliage color in Douglas-fir. In balsam fir, the color of needles is mainly correlated with nitrogen and phosphorus (Parent et al. 2005).

Poultry manure treatments tended to have higher Amax, soil respiration fluxes and specific leaf areas compared to the control and mineral treatments. Pirson (1958), Kramer and Kozlowski (1960), and Keller and Koch (1962) showed that nitrogen fertilization positively affects the maximum rate of photosynthesis of several plants. In this study, poultry 
manure treatments likely resulted in better availability of mineral elements in the soil solution, thus accounting for the trend of higher (though not statistically significant) Amax levels compared to other treatments. Also, the relatively high Amax in the control treatment could be due to a residual effect of the mineral fertilization yearly applied to those plantation trees prior to the beginning of the current study.

The increased $\mathrm{CO}_{2}$ flux observed in poultry manure treatments could result from a greater root respiration or a higher microbial activity associated with poultry manure. Enwall et al. (2007) found similar results in a study where soil respiration rates were highest with poultry manure as well as sewage sludge. The observed soil respiration values are similar to those obtained in other conifer studies; published data reported ranges of 1.83 to $7.08 \mu \mathrm{mol} \mathrm{m}^{-2} \mathrm{~s}^{-1}$ in radiata pine (Pinus radiata D. Don (Carlyle and Than 1988), 0.5 to 6.0 $\mu \mathrm{mol} \mathrm{m} \mathrm{s}^{-2} \mathrm{~s}^{-1}$ in Pinus taeda (Maier et al. 2002) and 1.67 to $5.87 \mu \mathrm{mol} \mathrm{m}^{-2} \mathrm{~s}^{-1}$ in ponderosa pine (Pinus ponderosa Douglas ex. C. Lawson (Xu and Qi 2001). Raich and Potter (1995) found a positive correlation between net primary productivity (NPP) and annual soil respiration. This trend has also been highlighted by Janssens et al. (2001). A high NPP generates high soil respiration fluxes and vice versa; increasing $\mathrm{CO}_{2}$ fluxes from the soil can also lead to an increase of NPP. Mineralization of soil organic matter, which produces fluxes of $\mathrm{CO}_{2}$, leads to the release of nutrients, including nitrogen, phosphorus and potassium that fertilize trees and directly influence vegetation growth. They are therefore interdependent factors. This phenomenon is particularly evident in boreal forests where nutrients are limiting (Perrin et al. 2004). Lower rates of photosynthesis and soil respiration observed in mineral fertilizer treatments may be due to a significant loss of nitrogen following application, as reported by Westerman and Tucker (1979) and Nissen and Wander (2003). Leaching can also be hypothesized in the current study, as an unusually high rainfall was observed in the region in June 2006 and June 2008 (Environment Canada 2018).

Specific leaf area is an index of the allocation of resources to the constitution of their leaf apparatus. Consequently, an increase in SLA results in a higher photosynthetic yield per unit mass (Lambers and Poorter 1992), which in turn would favor the allocation of carbon to other organs, especially at the level of the supporting tissues (trunk, branches) and the root system, all leading to a higher growth rate. Brix (1983) and Sheriff (1996) observed similar outcomes in tree growth experiments following an increase in leaf mass and area resulting from nitrogen fertilization. Although in the current study, poultry manure treatments increased SLA (Fig. 2), the SLA change did not result in a higher photosynthetic rate or higher height and diameter growth rates.

The poultry manure and mineral fertilizer treatments resulted in similar foliage concentrations of nutrients. It therefore appears that mineral elements from poultry manure, regardless of the frequency of application, are released in sufficient quantities through mineralization to maintain a level of nutrition comparable to that of trees fertilized with the mineral 20-10-10 fertilizer. Slesak and Briggs (2007) investigated the impact of mineral (ammonium nitrate) or organic (composted poultry manure) nitrogen fer- tilization on various Christmas tree species (Abies balsamea, Abies balsamea var. phanerolepis, Abies fraseri, Abies concolor and Pseudostuga menziesii). They observed that balsam fir responded well to organic fertilization when foliar nitrogen concentration was similar to that obtained through mineral fertilization.

In the current study, the controls had the lowest concentrations of many elements and nutrient ratios. However, concentrations always remained above critical levels reported for balsam fir (Slesak and Briggs 2007), and in adequate proportions, indicating the absence of any deficiency or toxicity. The somewhat surprising absence of $\mathrm{N}$ deficiency in the control treatment could be due to the residual effect of the fertilizer applied to the trees before the beginning of the experiment. All those confounding factors could be reasons for the small differences in nitrogen concentrations between the control and fertilized treatments.

Foliar analysis results indicated that calcium and iron concentrations appear to be deficient for all treatments. Caution should be exercised however, given that no specific study clearly established balsam fir's critical concentration levels of these two elements. According to Parent et al. (2005), the critical calcium concentration would be $0.57 \%$, indicating that this element would be slightly deficient for the trees in this study. The critical concentration of calcium would be $0.25 \%$ for other Christmas tree species such as the noble fir (Abies procera Rehder.) and Douglas-fir (Pseudostuga menziesii (Mirb.) Franco) (Hart et al. 2004), and some spruce and pine species (Landis et al. 1989). According to Hart et al. (2004), calcium deficiency is extremely rare when soil $\mathrm{pH}$ is greater than 5.0, which is the case in this study. Landis et al. (1989) reported that the critical concentration of iron is 60 $\mathrm{ppm}$, indicating that iron would be slightly deficient for the trees in this study. However, given the acidic $\mathrm{pH}$ (5.0 to 6.5) in the study sites, Fe is also presumed to be sufficient. Indeed, Hart et al. (2004) recommended a soil test to determine iron availability rather than relying on leaf analysis.

Since the mineral elements were almost all in adequate concentrations, it is not surprising to observe that height and diameter relative growth rates were not significantly different among fertilization treatments, even though the annual cutback of terminal shoots is a confounding factor for growth. Slesak and Briggs (2007) observed in several Christmas tree species a positive response of annual diameter increment to mineral and organic fertilization in comparison to the control. However, as in this study, they did not observe a positive effect of fertilization on the diameter growth for balsam fir.

\section{Conclusion}

Data from this study showed that the use of poultry manure resulted in similar, or sometimes better, growth performances when compared to the traditional formula of mineral fertilizer applied by Christmas tree growers of the region. Compared to the mineral fertilizer treatment, poultry manure treatments exhibited higher or marginally higher photosynthetic rates with higher specific leaf areas and soil respiration. Observations of height and diameter relative growth rates, foliage color and nutritional status (foliage concentrations of nutrients) showed similar results between poultry manure treatments and the traditional mineral fertil- 
ization, nonetheless, all better growth responses than by the controls. This study clearly showed that poultry manure can be used on Christmas tree farms as an alternative to the traditional mineral fertilizer formula used to obtain similar or even better growth performances. The results did not allow clear separation among the various fertilization treatments and identify the optimal poultry manure application. Although poultry manure requires 4.3 times the mass of mineral fertilizer to provide the same amount of nitrogen, it appears that its application would result in savings for growers, considering that it cost $\$ 80$ per metric ton compared to $\$ 400$ per metric ton for mineral fertilizer at the beginning of the study in 2004. An operational trial should be conducted to address the economic analysis of poultry manure use as a fertilizer in Christmas tree plantations of the region.

Finally, among the various rates of poultry manure applied in this study, the application of $1 \mathrm{~kg}$ of poultry manure per tree every two years could be recommended to producers because it has the advantage of cost saving in field operations, (biennal versus annual application), and manure quantity (1 kg versus $2 \mathrm{~kg}$ per tree).

\section{Acknowledgements}

M. Yves Boulet et M. Maurice Castonguay, Christmas tree growers and owners of the plantations where the experiment was conducted; the "École de Foresterie de l'Université de Moncton Campus d'Edmundston" for various inputs; the "Programme Initiative d'assistanat à la recherche de la Fondation de l'innovation du Nouveau-Brunswick (FINB)" and the "Programme Canada-Nouveau-Brunswick pour l'avancement de l'innovation dans les secteurs de l'agriculture et

l'agroalimentaire (PAISAA)" for providing the funds for this study; Munyonge Abwe Wa Masabo, Karl Roussel et Sébastien Therrien who helped with the fieldwork.

\section{References}

Albaugh, T.J., H.L. Allen, P.M. Dougherty, L.W. Kress and J.S. King. 1998. Leaf area and above and belowground growth responses of loblolly pine to nutrient and water additions. For. Sci. 44: 317-328.

Bauhus, J. and K. Khanna. 1999. The significance of microbial biomass and activity in forest soils. In: N. Rastin and J. Bauhus (eds.). Going underground: Ecological studies in forest soils. pp 77110. Research Signpost, Trivandrum, India.

Bondi, M.C., R.A. Fletcher, J. Hart, D. Hornbeck, C. Landgren and S. Webster. 2000. Douglas-fir Christmas trees: Oregon and Washington. Fertilizer Guide \#73. Oregon State University Extension Service, Corvallis, Oregon.

Brady, N.C. and R.R. Weil. 2002. The nature and properties of soils. 13th ed. Prentice Hall, New Jersey.

Brix, H. 1983. Effects of thinning and nitrogen fertilization on growth of Douglas-fir: Relative contribution of foliage quantity and efficiency. Can. J. For. Res. 13: 67-175.

Bruns, P.E. 1973. Cultural practices, fertilizing and foliar analysis of balsam fir Christmas trees. New Hampshire Agricultural Experiment Station, Durham. Bull. 501 p.

Carlyle, J.C. and U.B. Than. 1988. Abiotic controls of soil respiration beneath an eighteen-year-old Pinus radiata stand in Southeastern Australia J. Ecol. 76: 654-662.

Chabalier, P.F, V. Kerchove and H. Macary. 2006. Guide de la fertilisation organique à la Réunion. CIRAD, Chambre d'Agriculture de la Réunion, $304 \mathrm{p}$.
Cornelissen, J.H.C. 1999. A triangular relationship between leaf size and seed size among woody species: Allometry, ontogeny, ecology and taxonomy. Oecol. 118: 248-255. doi:10.1007/ s004420050725.

Diaz-Raviña, M., M.J. Acea and T. Carballas. 1993. Microbial biomass and its contribution to nutrient concentrations in forest soils. Soil Biol. Biochem. 25: 25-31. doi:10.1016/00380717(93)90237-6.

Edwards, D.R. and T.C. Daniels. 1992. Environmental impacts of non-farm poultry waste disposal: a review. Biores. Technol. 41: 933.

Elliott, L.F. and J.M. Lynch. 1994. Biodiversity and soil resilience. In: D.J. Greenland and I. Szabolc (eds.). pp 353-364. Soil Resilience and Sustainable Land Use, CAB International, Wallingford, UK.

Environment Canada. 2018. Historical climate data. http://climate.weather.gc.ca/index_e.html. [Accessed 24 July 2018].

Enwall, K., K.A. Nyberg, S. Bertilsson, H. Cederlund, J. Stenström and S. Hallin. 2007. Long-term impact of fertilization on activity and composition of bacterial communities and metabolic guilds in agricultural soil. Soil Biol. Biochem. 39: 106-115. doi:10.1016/j.soilbio.2006.06.015.

Field, C., J.M. Merino and H.A. Mooney. 1983. Compromises between water-use efficiency and nitrogen-use efficiency in five species of California evergreens. Oecol. 60: 384-389. doi:10.1007/ BF00376856.

Girvan, M.S., A.S. Bullimore, J.N. Pretty, A.S. Ball and A.M. Osborn. 2004. Responses of active bacterial and fungal communities in soils under winter wheat to different fertilizer and pesticide regimens. Appl. Environ. Microbiol. 70: 2692-2701. doi 10.1128/AEM.70.5.2692-2701.2004.

Guertin, J.F., M. Zitouni, P. Tanguay, R. Hogue and C. Beaulieu. 2018. Detection of Delphinella shoot blight in plantations of balsam fir (Abies balsamea) Christmas trees in Quebec, Canada. Can. J. Plant Path. doi: 10.1080/07060661.2018.1547791

Hart, J., R. Fletcher, C. Landgren, D. Horneck, S. Webster and M. Bondi. 2004. Christmas tree nutrient management guide for western Oregon and Washington. 28 p. Oregon State University, Extension Service. EM 8856-E.

Havlin, J.L., J.D. Beaton, S.L. Tisdale and W.L. Nelson. 1999. Soil fertility and fertilizers: An introduction to nutrient management. $6^{\text {th }}$ ed. 499 p. Prentice Hall, New Jersey.

Hinesley, L.E., L.K. Snelling and C.R. Campbell. 2000. Nitrogen increases fresh weight and retail value of Fraser fir Christmas trees. Hortic. Sci. 35: 860-862.

Imo, M. and V.R. Timmer. 1997. Vector diagnosis of nutrient dynamics in Mesquite seedlings. For. Sci. 43: 268-273.

Janssens, I.A., H. Lankreijer and G. Matteucci. 2001. Productivity overshadows temperature in determining soil and ecosystem respiration across European forests. Global Change Biol. 7: 269-278. doi:10.1046/j.1365-2486.2001.00412.x

Keller, T. and W. Koch. 1962. Der Einfluss der Mineralstoffernäfrung auf $\mathrm{CO}_{2}$-Gaswechsel und Blattpigmentgehalf der Papel. I. Mitt. Schweiz. Anst. forstl. Versuchsw. 38: 253-282.

Killham, K. 1994. Soil Ecology. Cambridge University Press, Cambridge, UK.

Kingery, W.L., C.W. Wood, D.P. Delaney, J.C. William, G.L. Mullins and E. Van Santen. 1993. Implications of long-term land application of poultry litter on tall fescue pastures. J. Prod. Agric. 6: 390-395.

Koelling, M.R. 2002. Fertilization recommendations for Fraser fir: Part II- established plantings. Michigan Christmas Tree J. 49: 5-8. Kramer, P.J. and T.T. Kozlowski. 1960. Physiology of Trees. McGraw-Hill Book co. Inc. New York City, NY.

Lambers, H. and H. Poorter. 1992. Inherent variation in growth rate between higher plants: A search for physiological causes and ecological consequences. Adv. Ecol. Res. 23: 187-261. 
Lambers, H., F.S. Chapin and T. Pons. 1998. Plant Physiological Ecology. Springer Verlag, Berlin.

Landis, T.D., R.W. Tinus, S.E. McDonald and J.P. Barnett. 1989. Seedling nutrition and irrigation: The container tree nursery manual, Vol. 4. Agric. Handbook. 674. USDA Forest Service. Washington, DC.

Langmaid, K.K., J.K. MacMillan and J.G.Losier. 1976. Soils of northern Victoria County, New Brunswick. Canada Department of Agriculture and New Brunswick Department of Agriculture. Fredericton, NB, Canada.

Langmaid, K.K., J.K. MacMillan and J.G. Losier. 1980. Soils of Madawaska County, New Brunswick. Agriculture Canada and New Brunswick Department of Agriculture and Rural development. Fredericton, NB, Canada.

Liu, B. and J.B. Ristaino. 2003. Microbial community structure in soils from organic and conventional agroecosystems. Phytopath. 96: S53.

Maier, C.A., K.H. Johnsen, J. Butnor, L. Kress and P. Anderson. 2002. Branch growth and gas exchange in 13 -year-old loblolly pine (Pinus taeda) trees in response to elevated carbon dioxide concentration and fertilization. Tree Physiol. 22: 1093-1106.

Margolis, H.A. and D.G. Brand. 1990. An ecophysiological basis for understanding plantation establishment. Can. J. For. Res. 20: 375-390.

Meason, D.F., D. Markewitz and R.E. Will. 2004. Annual fertilization and interspecific competition control: Effects on in situ forest floor nitrogen fluxes of different-aged Pinus taeda stands in southeast Georgia, USA. Can. J. For. Res. 34: 1802-1818.

Miller, H. 1981. Forest fertilization: Some guiding concepts. Forestry 54: 157-167.

Mitchell, A.K. and T.M. Hinckley. 1993. Effects of foliar nitrogen concentration on photosynthesis and water use efficiency in Douglas-fir. Tree Physiol. 12: 403-410.

Moore, P.A., T.C. Daniel, A.N. Sharpley and C.W. Wood. 1995. Poultry manure management: Environmental sound options. J. Soil Water Cons. 50: 621-627.

Munsell Color. 1977. Munsell Color Charts for Plant Tissues. Munsell Color. Baltimore.

Nissen, T.M. and M.M. Wander. 2003. Management and soil-quality effects on fertilizer-use efficiency and leaching. Soil Sci. Soc. Am. J. 67: 1524-1532.

Paarlahti, K., A. Paarlahti, A. Reinikainen and H. Veijalainen. 1971. Nutritional diagnosis of Scots pine stands by needle and peat analysis. Commun. Inst. Forest. Fenn. 74: 58.

Parent, L.E., L. Khiari and A. Pettigrew. 2005. Nitrogen diagnosis of Christmas tree needle greenness. Can. J. Plant Sci. 85: 939-947.

Perrin, D., E. Laitat, M. Yernaux and M. Aubinet. 2004. Modélisation de la réponse des flux de respiration d'un sol forestier selon les principales variables climatiques. Biotechnol. Agron. Soc. Environ. 8: 15-25.

Pirson, A. 1958. Mineralstoffe und Photosynthese. In: Ruhland (ed.). pp 355-381. Encyclopedia Plant Physiology, Spring-Verlag, Berlin.

Pritchett, W.L. and R.F. Fisher. 1987. Properties and management of forest soils. 2nd ed. John Wiley and Sons, New York, USA.

Raich, J.W. and C.S. Potter. 1995. Global patterns of carbon dioxide emissions from soils. Global Biogeochem. Cyc. 9: 23-26.

Richardson, B.W., E.D. Dickens and B.C. McElvany. 2004. Oldfield thinned loblolly pine plantation fertilization with diammonium phosphate plus urea and poultry litter: 4-year growth and product class distribution results. General Technical Report Southern Research Station. pp. 395-397. USDA Forest Service. N'.SRS71.

Sheriff, D.W. 1996. Responses of carbon gain and growth of Pinus radiata stands to thinning and fertilizing. Tree Physiol. 16: 527-536. Slesak, R.A. and R.D. Briggs. 2007. Christmas tree response to N fertilization and the development of critical $\mathrm{N}$ levels in New York. North. J. Appl. For. 24: 209-217.

Smolander, H. and P. Oker-Blom. 1989. The effect of nitrogen content on the photosynthesis of Scots pine needles and shoots. Ann. Sc. For. 46: 473s-475s.

Sommerfeldt, T.G., C. Chang and T. Entz. 1988. Long-term annual manure applications increase soil organic matter and nitrogen and decrease carbon to nitrogen ratio. Soil Sci. Soc. Am. J. 52: $1668-1672$.

Statistics Canada. 2016. Christmas ... by the numbers. https://www.statcan.gc.ca/eng/dai/smr08/2017/smr08_222_2017. [Accessed 24 July 24 2018].

Swift, M.J., O.W. Heal and J.M. Anderson. 1979. Decomposition in Terrestrial Ecosystems. In: U o C Press (ed.). Studies in Ecology. Berkeley, California.

Tejada, M., M.T. Hernandez and C. Garcia. 2006. Application of two organic amendments on soil restoration. Effects on the soil biological properties. Journal of Environ. Qual. 35: 1010-1017.

Teskey, R.O., H.L. Gholz and W.P. Cropper. 1994. Influence of climate and fertilization on net photosynthesis of mature slash pine. Tree Physiol. 14: 1215-1227.

Timmer, V.R. and E.L. Stone. 1978. Comparative foliar analysis of young balsam fir fertilized with nitrogen, phosphorus, potassium and lime. Soil Sci. Soc. Am. J. 42: 125-130.

Van Groenewoud, H. 1983. Summary of climatic data pertaining to the Climatic Regions of New Brunswick. Information Report M-X-146, Maritimes Forest Research Centre, Fredericton, New Brunswick.

Van den Driessche, R. 1974. Prediction of mineral nutrient status of trees by foliar analysis. The Bot. Rev. 40: 347-393.

Vose, J.M. and H.L. Allen. 1988. Leaf area, stem wood growth, and nutrition relationships in loblolly pine. For. Sci. 34: 547-563.

Westerman, R.L. and T.C. Tucker. 1979. In situ transformations of nitrogen-15 labelled materials in Sonora Desert soils. Soil Sci. Soc. Am. J. 43: 95-100.

Westoby, M. 1998. A leaf-height-seed (LHS) plant ecology strategy scheme. Plant and Soil 199: 213-227.

Wilhoit, J., T. Stokes, L. Samuelson and J. Johnson. 1999. Influence of poultry litter fertilization 18-year-old loblolly pine stand. Comm. Soil Sci. Plant Anal. 30: 509-518.

$\mathrm{Xu}, \mathbf{M}$., and Y. Qi. 2001. Soil surface $\mathrm{CO}_{2}$ efflux and its spatial and temporal variations in a young ponderosa pine plantation in northern California. Glob. Chang. Biol. 7: 667-677. 